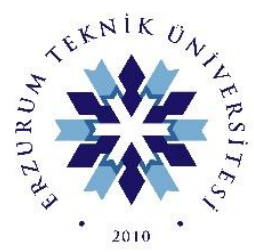

ÇAĞDAŞ SOSYAL HİZMET ÇALIŞMALARININ FELSEFİ VE TARİHSEL UĞRAĞI: MICHEL FOUCAULT

THE PHILOSOPHICAL AND HISTORICAL HAUNT OF CURRENT SOCIAL WORK STUDIES: MICHEL FOUCAULT

\author{
Uğur DAŞTAN \\ Dr., Remzi Sakaoğlu Bilim ve Sanat Merkezi \\ dr.ugur.dastan.@gmail.com \\ https://orcid.org/0000-0002-7369-9049 \\ ETÜ Sosyal Bilimler Enstitüsü Dergisi |ETU Journal of Social Sciences Institute \\ S.11, Ekim | October 2020, Erzurum \\ e-ISSN: 2717 - 8706
Makale Türü | Article Types ： Araştırma Makalesi |Research Article
Geliş Tarihi | Received Date $\quad: \quad 15.09 .2020$
Sayfa|Pages : $130-158$
d $\quad$ : http://dx.doi.org/10.29157/etusbe.2020.57 \\ Kabul Tarihi |Accepted Date $\quad: 16.10 .2020$ \\ https://dergipark.org.trletusbed \\ This article was checked by \\ $\checkmark$ iThenticate
}






\title{
ÇAĞDAŞ SOSYAL HİZMET ÇALIŞMALARININ FELSEFI VE TARİHSEL UĞRAĞI: MICHEL FOUCAULT
}

\author{
Uğur DAŞTAN
}

ETÜSosyal Bilimler Enstitüsü Dergisi (ETÜSBED), S .11, Ekim 2020, Sayfa: 130-158

\begin{abstract}
ÖZ
Ünlü Fransız düşünür Michel Foucault, genellikle yirminci yüzyılın postmodern düşünürleri arasında gösterilir. İktidar etkilerine göre şekillenen modernite olgusunun ve bu olguya dayalı teorik ve pratik yapıların eleştirildiği Foucault felsefesinde, modern dönem içerisinde ortaya çıkan sosyal hizmet alanına referans olabilecek görüşlere de rastlamak mümkündür. Bu araştırmada özellikle tımarhane, klinik ve hapishane örneklerinden hareketle, Foucault'nun sosyal hizmet alanını doğrudan ilgilendiren eleştirilerine yer verilmiştir. Foucault tımarhaneleri incelerken delinin toplumdan dışlanması sorunsalına ait eleştirilere yer verir. Klinikler üzerine tartışmalarında modern bilimle başlayan teşhis ve tedavi yöntemlerini insani değerler açısından ele alır. Hapishaneler söz konusu olduğunda ise bu kez modern bilim ve modern hukuk sistemleri arasında sıkıştırılan insanın kendi varoluşuna yabancılaşmasını tartışı. Bu tartışmalar Foucault'nun sosyal hizmet alanına temel teşkil edecek çalışmalar yaptığının bir göstergesidir. Bu çalışmanın amacı sosyal hizmet alanında faaliyet gösteren kurumların Batı'daki gelişim öykülerine odaklanmanın yanı sıra bu öykülerin günümüz sosyal hizmet çalışmalarında teorik ve pratik anlamda ne gibi katkılar sunduğuna dair felsefi bir perspektif sunmaktır.
\end{abstract}

Anahtar Kelimeler: M. Foucault, Sosyal Hizmet, Timarhane, Hastane, Hapishane

\section{THE PHILOSOPHICAL AND HISTORICAL HAUNT OF CURRENT SOCIAL WORK STUDIES: MICHEL FOUCAULT} ABSTRACT

The prominent French thinker Michel Foucault is commonly considered among the postmodern thinkers of the twentieth century. In Foucault 's philosophy, where the phenomenon of modernity, influenced by the effects of power and theoretical and practical structures based on this phenomenon is criticized, it is possible to come across views that can be a guide to the area of social work that has arisen in modern times. In this research, Foucault's critique is linked directly to the field of social work, in particular with regard to the representations of madhouses, hospitals and prisons. While Foucault studies madhouses, he gives rise to criticism of the issue of the isolation of the mad from society. In his discussions on clinics, he dealt with diagnostic and care approaches, beginning with modern science in terms of human values. In the case of prisons, this time, he addresses the alienation of the human being trapped between modern science and modern legal systems. These discussions indicate that Foucault's works can be assessed as a basis for social work studies. The goal of this study is to concentrate on the growth of the stories of institutions working in the field of social work in the West, as well as to provide a philosophical perspective on what these stories relate in theoretical and practical terms to today's social work studies.

Keywords: M. Foucault, Social Work, Madhouse, Hospital, Prison 


\section{Giriş}

Günümüz toplumsal yapısının en önemli alanlarından birisini hiç kuşkusuz sosyal hizmet uygulamaları oluşturmaktadır. Ulusal veya uluslararası ölçeklerde oluşturulmuş kamu ya da özel kuruluşlar vasıtasıyla yürütülen ve birbirinden tamamen farklı organizasyonların bütünü şeklinde tanımlanabilecek olan sosyal hizmetin, doğrudan her bir bireye ulaşmaya çalışan ve var olan imkânlardan, bireylerin eş değerde yararlanılmasını amaç edinen bir alan olduğu söylenebilir. Bu anlamda, toplumsal gelişmişlik düzeyinin olmazsa olmaz bir uygulaması olarak karşımıza çıkan sosyal hizmet, diğer tüm alanlarda olduğu gibi çağın gereklerine göre şekil alan ve baş döndürücü hızdaki değişimlerin sürekli olarak yaşandığı bir faaliyet alanıdır. Sosyal hizmet gereklidir ve eğer toplumsal yapının eşitlik ve adalet ekseninde devamı ve işlevselliği korunmak isteniyorsa her dönemde çağın ihtiyaçlarına göre sosyal hizmet faaliyetlerinin güncel ve kaliteli bir biçimde sunulması elzemdir.

Sosyal hizmetin gerekliliğine ilişkin hemen hemen her bir bireyin taşıdığ1 genel kanının aksine gerçekte sosyal hizmetin ne olduğuna ilişkin akademik çevrelerce ortaya konulan tartışmaların varlığı ise oldukça şaşırtıcıdır. Bu anlamda, hitap edilen kitlenin genişliği ve uygulama alanlarının çokluğu sebebiyle bu alanda çalışan kişiler tarafından dahi tam olarak tanımlanması mümkün olmayan soyal hizmet için çoğunlukla hem mesleki bir hizmet hem de uygulamalı bir bilim olduğu şeklinde çift yönlü bir kabul vardır (Duyan, 2003: 2-3). Bu çift yönlü kabule dayalı bir biçimde modern bir alan olan sosyal hizmetin, diğer birçok modernite uygulamasında olduğu gibi köklerini Antik Yunan'a kadar geriye götürmek ve mevcut bu tarihsel süreç ekseninde genel çerçevesini çizmeye çalışmak mümkün olsa da, gerek ilgilendiği unsurların insan ve sosyal konular olması gerekse de tüm bu tarihsel serüven esnasında şekillendiği yapıların sürekli değişimi düşünüldügüünde, tanımıyla ilgili tartışmaların da en az sosyal hizmet alanının uygulamalarında karşılaşılan sorunlar kadar çağı aşan bir probleme dönüştüğü anlaşılır (Doel, 2012: 5).

Sosyal hizmetin tanımı ve devamında içeriğiyle ilgili belirsizliklerin temelinde sosyal hizmet uygulamalarının bilimle ne türden bir ilişki kurduğu meselesi saklıdır. Bu ilişki aynı zamanda sosyal hizmetin teorik alt yapısının da serüvenidir. Akademik ve bilimsel bir disiplin olarak uzunca bir dönem Batı' da rasyonel ilkelerle birlikte ve nicel değerlendirmeler ışığında ortaya konulan sosyal hizmet, en az psikoloji, sosyoloji ve felsefe kadar etkin teorik ürünlerin sergilendiği pozitif bir bilimsel çerçeveyi anımsatır (Doel, 2012: 7). Bununla beraber mesleki bir yaklaşım olarak sosyal hizmet, başlangıçtan beri bilimi kendi 
pratikleri açısından bir temel olarak kullanmıştır (Kirk \& Reid, 2002: 49). Bu kullanım, diğer mesleklerin bilimi kullanmasına paralel bir biçimde ya mesleki faaliyetlerin yürütülmesinde bilimsel bir modeli takip etmek ya da mevcut faaliyetlerde (eğitim programları, finansal kaynaklar, organizasyon ortamları, vb.) ihtiyaç duyulan bilgilendirmeyi yapmak için bilimsel bilgilerden faydalanmak şeklinde kendini gösterir (Kirk \& Reid, 2002: 26). Tüm bu unsurlar, bilim ile sıkı ilişki içerisinde olan sosyal hizmetin, gelişen düşünce dünyasına entegre olması için gerekli koşullara uyum sağlamasını zorunlu kılar. Bu nedenle bilim dünyasında değişen paradigmalara bağlı olarak sosyal hizmet alanında da benzer değişimler bir zorunluluk olarak yaşanır.

Sosyal hizmetin bilimle olan bu ilişkisinin yanı sıra hem kamu hem de özel alanda yapılan çalışmaların bir bütünü olması hasebiyle politik yapı ile de doğrudan bir ilişki içerisinde olduğunu söylemek mümkündür. Kaldı ki, bu ilişki tıpkı sosyal hizmetin bilimle olan ilişkisi içerisinde kendini ve faaliyetlerini tanımlamasında yaşanan sorunlara eş değer bir biçimde, sosyal hizmetin zaman içerisinde uygulamalar noktasında yaşanan değişimlerinin de ana eksenini oluşturur. Özgürlük, adalet, hukuk, hak vb. birçok olgu, zaman içerisinde değişen toplumsal yapılara veyahut siyasi anlayışlara göre farklılık arz eder ve bu farklılıklar sosyal hizmet alanını her anlamda etkiler. Nitekim siyasi aktörler ya da güçlerin belirleyici olduğu sosyal politikaların sunduğu içgörüler, sosyal hizmet becerileri ve ayrımcılıkla mücadeledeki uygulama taahhütleri ile yan yana geldiğinde, daha entegre ve etkili bir uygulama olasılığını ortaya koyar (Parrott, 2001: 20).

Sosyal hizmetin gereği ve ne olduğuyla da ilgili olarak ortaya konulan tartışmaların yanı sıra zaman içerisinde kendisini güncellemek adına değişen fikri zemini de göz önünde bulundurulduğunda, bu çalışmanın ana iskeletini oluşturan Fransız düşünür Michel Foucault'nun, sosyal hizmet pratiğinin tarihsel bağlamını ortaya koymak ve kuramsal çerçevesini oluşturmak bakımından ne denli önemli bir düşünür olduğu açıkça ortaya çıkar. Zira Foucaultcu perspektife vakıf olan herkes için Foucault, hem ele aldığı konu ve olgular hem de bu konu ve olgulara ilişkin tarihsel anekdotları ile sosyal hizmet alanı için eşine ez rastlanır bir kaynaktır. Her ne kadar geçtiğimiz yüzyılın ortalarındaki haliyle sosyal hizmetin ve o dönem sosyal hizmetin yoğun ilişki içerisinde olduğu psikiyatri gibi kimi insan bilimlerinin varlığına ilişkin tek bir merkezden yöneltilmeleri, iktidar merkezleri tarafından oluşturulmuş birer alan olmaları (Whitebook, 2005: 332) ve sosyal hizmet uygulamaları adı alında yapılan faaliyetlerdeki dikkat ve düzeltme işlemlerinin aslında gerçeği görmemek adına insan için birer oyalama taktiği içermesi nedeniyle olumsuz bir 
tavır taşıyor (Santos, 2006: 1) olsa da Foucault'nun özellikle delilik olgusu üzerinden tımarhaneleri, suçlu olgusu üzerinden hapishaneleri ve son olarak hasta olgusu üzerinden klinikleri tüm çağlardan günümüze gelişim öyküleri ile birlikte ele aldığı temel eserlerinde, başka hiçbir kaynakta kolaylıkla bulunamayacak bir sosyal hizmetler tarihi sunulur.

$\mathrm{Bu}$ eserlerde aktarılan tarihsel tablo ve değinilen hususlarda kullanılan dispozitiflerin, asıl dayanak noktasını kapatma mefhumu oluşturur ve Foucault kapatma eylemlerinden hareketle, insan olgusunu hem içerden hem de dişardan gelebilecek iktidar baskılarına karşı bilimsel mecradan ahlaki alana kadar uzanan geniş bir zeminde tartışmaya açar. Bir yandan iktidar eliyle hazırlanan ve ortaya çıktığı dönem itibariyle din, bilim, toplumsal değerler vb. tarafından belirlenen kapatma mekanizmaları içerisinde mevcut iktidara karşı ötekileştirilen insanı, öte yandan toplumsal bir varlık olması hasebiyle kendi kendine uyguladığı iktidara dayanarak özüne yabancılaşan insanı ele almaya çalışan Foucault, insanın bu kadar geniş bir bakış açısıyla ele alınmasındaki zorunluluğu, iktidarın her yerde olmasına bağlar (Foucault, 1977a: 176; Foucault, 1976a: 69). İktidarın her yerdedir ve onun bu kuşatıcı rolü bireyi içinden çıkılamayan bir sistemin parçası haline getirirken, eylemlerinin ya da varlığının sorgulanmasında dar kalıplardan sıyrılmayı da bir zorunluluk haline getirir. İnsanın bu denli geniş bir zeminde ele alınmasının bir diğer nedeni; iktidarın çok bilinenin aksine baskıcı bir unsur olmaması, tem tersine zevk bile üretebiliyor olmasıdır (Foucault, 1976a: 61; Foucault, 1975a: 49). Öyle ki, doğrudan arzularımıza, isteklerimize ya da diğer psişik olgularımıza işleyen iktidar, kendisine yabancılaştırılan insanın damarlarında gezinir. Bu uyku halinden insanın kurtulması için daha geniş bir zeminde ve çok boyutlu bir tartışma yürütmek gerekir. Buradan hareketle, doğrudan kurumlar ve toplumsal yapılar vasıtasıyla veya dolaylı olarak hazlar aracılığıyla bireyin kendisiyle özdeşleşen iktidarın her alana yayılması ve insanın varlığına sürekli nüfuz etmesi, Foucault'yu haklı olarak insanı ele alırken daha derinlemesine tahlillere itmiş ve sonuçta günümüz itibariyle onu bir uzmanlık alanı olan sosyal hizmetin konu alanına ilişkin bir figür haline dönüştürmüştür. Üstelik Foucault görüşlerini ortaya koyarken esasında sosyal hizmetin bilimsellik iddiaları ile ilgili açmazlarını serimlemeyi ve tanımında yatan ve özünü insanın oluşturduğu karmaşık teorik alt yapısını zenginleştirmeyi amaç edinir. Bunun yanı sıra iktidarın ilişkili olduğu politik yapılarla paralelliğini irdeleyebilmenin olasılıklarını artırır.

Tüm bu bilgiler ışığında, bu çalışmada, üniversite yıllarında felsefe eğitiminin yanı sıra günümüz sosyal hizmet çalışmalarının şekillenmesinde 
önemli bir zemin teşkil eden psikoloji alanında da eğitim almış olan ve ilk eserinde ruhsal hastalıkların incelenmesi hususundaki eksikliklere yer veren (Urhan, 2013: 11) Foucault'nun; tımarhaneler, klinikler ve hapishanelere ilişkin görüşleri, tarihsel gelişim süreçleri açısından ele alınacaktır. Bu kurumlar üzerinden yapılan Foucaultcu değerlendirmelerin, çok genç bir alan olan sosyal hizmet uygulamaları ve uygulayıcıları açısından nasıl bir önem arz ettiği aktarılarak, sosyal hizmet uygulamalarındaki çok yönlü değişimlerin ardındaki düşünsel zemine katkı sunulmaya çalışılacaktır. Ayrı ayrı başlıklar etrafında hem bu kurumların zaman içerisinde nasıl şekillendiği hem de bu şekillenme esnasında iktidarın gerek bilim gerekse farklı biçimlerde insan üzerinde kurduğu tahakkümün yansımaları, çalışmanın ana eksenini oluşturacaktır.

\section{Timarhaneler}

Delilik ve tımarhanelerin Batı'da vücuda gelme biçimi, Foucault'nun ilk olarak ele aldığı ve sonraki tüm düşünceleri için bir başlangıç noktası oluşturan, en kapsamlı konuların başında gelir. Kapatılmanın en bariz göstergesi olan tımarhanelerin yaygın bir biçimde varlığından söz ederken, Foucault, genel anlamda diğer arkeolojik çalışmalarında da olduğu gibi Rönesans, Klasik Çağ ve Modern Çağ olmak üzere üç dönem üzerinden bir okuma gerçekleştirir. Bu anlamda, Rönesans dönemi öncesinde Orta Çağ'da delilerin belediyeler vasıtasıyla şehirlerden toplanması ve limanlar arası dolaşan gemilere (Narrenschift) hapsedilerek, sosyal hayattan uzaklaştırılması Foucault'ya göre bilinen en yaygın uygulamalardan ilki olarak karşımıza çıkar (Foucault, 1961: 31-32). Öyle ki, deli ve su gibi iki unsuru birbirine bağlayan söz konusu bu uygulama efsanelere dahi yansır. Bir gemi vasıtasıyla deli kılığında Cornwell kıyılarına geldiği ve kralın huzura çıktığını anlatan meşhur efsanede, Trestan, Kral Marc'ın şatosuna girdiğinde kimse tarafından tanınmamış ve yine kimse onun nereden geldiğini bilememiştir (Foucault, 1961: 37). Bu efsane, deli gemilerinin varlığına ilişkin somut bir kanıt içermesinin yanı sıra toplumda delilerin kim ve nereli olduğu ile ilgili herhangi bir kaygının taşınmıyor oluşunu da işaret etmesi bakımından oldukça önemlidir. Yine bu dönemde, deli gemilerine hapsedilenlerin yanında hemen her fırsatta yerleşim merkezlerinden uzaklaştırılan delilerin, Almanya gibi bazı ülkelerde geleneksel olarak bir tüccar ya da hac kafilesi ile uzaklara gönderilmesi de sıkça rastlanılan bir durumdur (Foucault, 1961: 32). Tüm bu uygulamalarda amaç, "normali" korumak adına "anormal" olarak nitelendirilen delilerin sürgün edilmesidir. Bu açıdan kapatılma safhasından önce bir anlamda yok sayılan delilerin, toplumdan topluma dolaşabilmelerinden kaynaklı kısmi bir özgürlüklerinin var olduğu 
düşünülse de esasında Orta Çağ'in bütünü boyunca kiliselerde cüzzamlılara uygulanan tecridin bir benzeri ile karşı karşıya kaldıkları da açıktır.

Bütün Orta Çağ boyunca adeta süreklilik arz eden toplumsal yapılardan uzaklaştırılarak kendi kaderlerine terk edilen delilerin, Rönesans'in başlangıcında, Foucault tarafından da memnuniyetle karşılanan bir bakış açısıyla kısa süreliğine de olsa parlak bir dönem geçirdiği anlara da rastlanır. $\mathrm{Bu}$ bakış açısının hayat bulduğu alanlar ise edebiyat ve tiyatrodur. Önceleri toplumda önemsenmeyen, işe yaramaz bir nesne muamelesi gören ve oraya buraya sürülen deliler, birdenbire edebi eserlerin başkahramanları ve tiyatroların baş aktörleri haline dönüşür. Orta Çağ'da kusurlar hiyerarşisi içerisine yerleştirilen deli, Rönesans'la birlikte, birinci sıraya yükselerek, insanın bütün zayıflıklarını yöneten bir koro şefi vazifesi görür (Foucault, 1961: 52). Artık âşıklara aşkı, gençlere hayatın gerçeklerini söyleyen deli, bu yönüyle bilgelik misyonunu üstlenir (Foucault, 1961: 39-40). Tuhaf bir değişim içerisinde hakikatin sözcüsü konumuna yükselen deli, artık herkesin kendisinden bir şeyler öğrenmeye çalıştığı bir rol model ve toplumsal hafızalara ışık tutan bir fenerdir.

Deliliğin edebiyat ve tiyatro vasıtasıyla edindiği ve Foucault'nun da takdir ettiği bu prestijli konum, aynı dönemde çok geçmeden Brat ve Erasmus gibi düşünürler vasıtasıyla hümanizma gerekçe gösterilerek tekrar bertaraf edilir. Tüm silahlarını kaybeden delilik aniden söylem evreninin içine atılır ve hakikate giden yol olma özelliğini kaybeder (Foucault, 1961: 59-60). Kartezyen felsefenin başlangıcını da simgeleyen bu dönem Klasik Çă̆’dır. Rasyonel düşünme biçimlerinin ağırlık kazandığı Klasik Çağ'da delilik, zihinsel bir hastalık olarak akli olanın zıttı bir olguya dönüşür. Delilik aklın yokluğudur ve her ne pahasına olursa olsun yine akıl ilkeleri doğrultusunda kontrol altına alınmalıdır. Rasyonel eğilimlerin oluşturduğu bu delilik algısı, beraberinde on yedinci yüzyılda kapatmanın pratik anlamda vücuda geldiği haliyle, kapatma evlerini, sosyal hayatın bir gerçeği haline dönüştürür. Başlangıçta Almanya ve İngiltere örneklerinde olduğu gibi büyük kapatma evlerinin çoğunlukla manastır, kilise vb. dinsel kurumlarda ortaya çıkışına rağmen (Foucault, 1961: 102-103) on yedinci yüzyılla birlikte kapatma evleri tamamen siyasal kararlara göre oluşturulan kurumlara dönüşür. Zira bu kurumlarda mühürlü zarflar içerisinde birçok keyfi kapatmanın yapıldığı herkes tarafından bilinir (Foucault, 1961: 89). İster dinsel ister siyasal olsun kapatma evlerinin işlevsel olup olmadığı, içerisinde barındırdığı kişilerin sayısı ile ölçülür. Çünkü bu sayı aynı zamanda mevcut sistematiğe aykırı kişilerin de ne kadarıyla ayıklandığını gösterir. 
On yedinci yüzyılda devlet ve din eliyle gerçekleştirilen bu kapatma eylemlerinde iki temel dayanak noktası vardır. Birincisi kapatılmaya razı olan ve böylelikle mutlu olacağına inanan kişilerin kapatılmasıdır ki, burada dinsel ağırlıklı bir teoriden söz edilebilir. İkincisi ise bunu reddedenlerin düzeni bozacağı endişesiyle kapatılmasıdır ki, burada da siyasal seçimlerin ağırlıklı bir rolü vardır (Foucault, 1961: 137-138). Her ne sebeple olursa olsun deliler akıl sahibi olanlardan rasyonel ilkelere bağlılık güdüsüyle ayrılır ve dışlanır. Dışlamanın boyutları gün geçtikçe artar ve belli bir zaman sonra "Genel Hastane" adı verilen kurumların ortaya çıkmasıyla birlikte sadece deliler değil; meczuplar, fakirler, kimsesizler gibi birbirleriyle alakası olmayan ama toplumsal işleyişe zarar verdiği düşünülen tüm gruplar bir arada kapatılma eylemine maruz kalır (Foucault, 1961: 89). Genel Hastane, adının aksine tıbbi bir kurum değildir. Daha çok yarı adli bir kurum mantığıyla oluşturulan bu yapılarda, monarşi ve burjuvazi mantığının ete kemiğe büründürüldüğü bir gözetim mekanizması tasarlanır (Foucault, 1961: 92). Genel Hastane'lerin ortaya çıktığı Hamburg, Paris ya da Londra gibi ilk Avrupa şehirlerine bakıldığında, bu şehirlerin ekonomik açıdan diğer şehirlere oranla daha çok canlılı̆̆ın yaşandığı şehirler olması ise bir tesadüf değildir. Çünkü bu şehirlerde ortaya çıkıp daha sonra öncelikli olarak diğer ekonomik merkezlerde yaygınlaşan bu hastaneler, kapatmanın ekonomik açıdan bir çözüm olarak görüldüğünün de ispatıdır. Özellikle Avrupa tarihi açısından ekonomik bunalımların ve işsizliğin çok görüldüğü dönemlerde uzunca bir süre işsizlere ve serserilere de ev sahipliği yapan Genel Hastaneler, doğrudan çoğunluğun refahını diri tutmanın alternatif bir kurumu olarak görülür (Foucault, 1961: 116-117). Birbiri ile alakası olmayan ve farkl1 toplumsal kesimlerden gelen insanlar, bu hastanelerde bir araya getirilerek, var olan sorunlar görmezden gelinir.

Genel Hastane uygulamaları ile birlikte ekonomik olduğu kadar toplumsal bir öteki haline de dönüşen deli figürü, aynı zamanda tamamen her alana yayılan gözetim mekanizmasının da en belirleyici unsuru haline gelir. Burada kimi zaman bir suçlu kimi zaman ise ekonomik değerleri örseleyen bir unsur olarak kabul edilen deli; sefil, fakir, serseri, işsiz vb. kendisiyle ilişkisi olmayan diğer toplumsal sınıfların da ortak adına dönüşür. Tabi bu dönüşüm başka olguların da ortaya çıkmasına neden olur. Örneğin; Foucault'ya göre kapatılanlara uygulanan bu ayrım yabancılaşmanın yaratıcısı olarak tarihe geçer (Foucault, 1961: 138). Toplumun farklı kesimlerinden gelen ve toplumsal işleyişi olumsuz yönde etkilendiği düşünülen bu sınıflar, kapatma ilkesiyle birlikte birbirine yaklaştırılır ve sonunda mevcut işleyişi daha etkin kılmak yerine özellikle ahlaki yapılarda yeni ve onulmaz yaraların açılmasına neden olur 
(Foucault, 1961: 141). Özellikle bu sorunun aşılması için ahlakın da tıpkı ticaret ve ekonomi gibi yönetilmeye razı olduğunu söyleyen Foucault, Genel Hastanelerin de buna uygun bir biçimde Klasik Çăğ'ın sonuna doğru ahlaki bir statüye bürünmek zorunda kaldığını iddia eder (Foucault, 1961: 127-129). Burada deliliğin ahlaki bir kaygıyla toplumsal duyarlılığı tetiklediği doğru olsa da bu duyarlılığın çağımızdaki gelişim süreci düşünüldüğünde oldukça ilkel kaldığı da bir gerçektir. Dolayısıyla Genel Hastaneler üzerinden büyük bir kopuş yaşandığını ve Rönesans dâhil önceki dönemlerde görülmeyen bir dışlanmanın bu döneme has uygulamalar sonunda ortaya çıktığı iyice anlaşılmalıdır (Foucault: 1970a: 265). Edebiyat ve tiyatroda ele alınan biçimleri istisna olmak kaydıyla, önceki dönemlerle mukayese edildiğinde gelişim göstermesi gereken delilliğe ait teorik ve pratik uygulamaların, sorunu daha karmaşık hale getirmesi, üzerinde düşünülmesi gereken bir husus olarak düşünce tarihindeki yerini alır.

Rönesans ve Klasik Çağ sonrası Modern Çă̆’a gelindiğinde ise deliliğin bir hastalık olarak tanımlanmaya başladığı görülür. Bu tanımlama, Klasik Çağ itibariyle gelinen ahlaki, ekonomik ve siyasi belirsizlikler sonucunda dışlanan delinin, yeniden toplumsal yapıda anlamlandırılması için girişilen çabanın faklı bir veçhesidir. Özellikle birçok Avrupa uygarlık ve düşünce tarihçisi deliliğin bu anlam değişiminde, İngiliz William Tuke ve Fransız Philippe Pinel' in önemli katkıları olduğunu iddia eder (Foucault, 1978: 214). 1793 yılında Fransa'da Fransız Devrimi sırasında bir hekim olan Pinel, Bicétre ${ }^{1}$ adında bir tımarhaneye müdür olarak atanır (Foucault, 1961: 667-669). Klasik Çăğ'in ruhuna uygun olarak aslında hapishane olarak inşa edilen bu yapıda barındırılan ve tehlikeli olarak kabul edilen kapatılmış grupların bir kısmını, Pinel, göreve başlar başlamaz salıverir. Bundan böyle buranın bir kapatma mekânı olarak kullanılmayacağını, hücre ve zincirlerin tamamen kaldırılacağını ilan eder. Burada yalnızca hasta ve bakıma muhtaç kişilere hizmet verileceğini ve bu nedenle artık sadece hekimlerin bu kurumda görev alacağını tüm şehir halkına bildirir (Foucault, 1978: 214). Pinel'in ortaya koyduğu delilere ilişkin bu yaklaşımın bir benzeri hemen hemen aynı tarihlerde bu kez İngiltere' de W. Tuke tarafından ortaya konulur. Nitekim Tuke, dar anlamıyla günümüzde psikiyatri

\footnotetext{
${ }^{1}$ Foucault Tokyo' da verdiği ve dilimize “Delilik ve Toplum” şeklinde çevrilen konferansta, deliliğin hasta formatı altında incelenmesinin dönüm noktasından bahsederken Pinel'in atanmasının 1792 tarihinde Salpétriére'e olduğunu söyler. Ancak bu döneme ilişkin açıklamaların daha yoğun olduğu Deliliğin Tarihi adlı eserinde, gerekli tarihi referansları da vererek, Pinel' in ilk önce atandığı kurumun 25 Ağustos 1793'te Bicétre, daha sonrasında 13 Mayıs 1975'te Salpétriére olduğunu ve metinde bahsi geçen hastaların ilk salıverilme hadisesinin Bicétre' de gerçekleştiğini aktarır. Bu nedenle, bu çalışmada daha detaylı bilgilerin yer aldığı Deliliğıin Tarihi'ndeki bilgiler referans alınmıştır.
} 
kliniği denilebilecek ilk kurumsal yapıyı, York şehrinde faaliyete geçirir ve çok geçmeden bu kurumların sayısı Avrupa genelinde hızla artar (Foucault, 1978: 214). Pinel ve Tuke ile başlayan ve deliliği ruhsal bir hastalık olarak gören bu yeni yaklaşım, aslında Foucault açısından mevcut iktidar baskısının sadece kılıf değiştirmesinden ibaret bir hamledir. İktidar, bu kez, özellikle on sekizinci yüzyılla birlikte başlayan insan bilimlerine bir model arama çalışmalarında da olduğu gibi bilim ile doğrudan eklemlenmek suretiyle yeni bir strateji geliştirir.

Tımarhaneler bu yeni anlayışla birlikte artık geçmişte olduğu gibi delilerin ve suçluların bir arada belli yaptırımlara maruz kaldıkları bir yer değildir; ama bu kez çok daha fazlasının yapıldığı bir yer haline dönüşmüştür. $\mathrm{Bu}$ yeni tip yapılarda deli düzenlenmekte ve sinıflandırılmaktadır (Foucault, 1961: 688). Özellikle pozitivist anlayışların ağırlığını iyiden iyiye hissettirdiği on sekizinci yüzyılın sonları ile on dokuzuncu yüzyılda, tımarhaneler, özgür biçimde teşhis, gözlem ve tedavilerin yapıldığı bir alan olmaktan çok öte delilerin itham edildiği ve yargılandığı kurumlar haline gelir (Foucault, 1961: 713). Tımarhanelerde görev alan doktorlar, gözetim altında tutan, gözetleyen ve daha iyi görmek için deliye yaklaşan kişidir. Sadece göründüğü haliyle var olan deliyle, deli olmayan, bilinçli bir iktidar eliyle ve sistematik bir biçimde karşı karşıya getirilir (Foucault, 1961: 692). Öyle ki, belli yasal düzenlemelerle delilerin bu yeni tip tımarhanelere getirilmesi için aileler teşvik edilir ya da cezalandırılır (Foucault, 1970b: 79-80). Bu durum, Modern Çağ'da ortaya çıkan yeni tımarhanelerin bilimsel modeli kullandığı kadar hukuk sistemlerini de deliyi ötekileştirmek için programına aldığını gösterir.

Foucault açısından Modern Çağ' da ortaya çıkan tüm bu gelişmeler, aynı zamanda doğrudan ekonomik gerekçelerin de delilikle olan ilişkisini güncellediğini gösterir. Özellikle kapitalist anlayışların teorik zeminde yeni yeni ete kemiğe büründüğü bu yüzyılla birlikte delilerin, bir hasta olarak ele alınmak istenmesinin altında yatan nedenler iki başlık altında toplanabilir. Birincisi; geçekten deli diye nitelendirilen ve herhangi bir iş gücü oluşturamayacak olan grupları, her türlü üretim ve tüketim faaliyetinden uzak tutmaktır. İkincisi; daha önce uygulanan ve kapitalizmin yoğun baskısıyla değişen kapatma uygulamalarında iş gücü oluşturabilecek kişileri bir şekilde üretme faaliyetlerinde kullanmaktır. Nitekim Pinel'in boşalttığ 1 iddia edilen Bicétre'deki tımarhanede sadece ekonomik açıdan iş gücü oluşturanları salıverip, çalıştırılması mümkün olmayanları içerde tutması manidardır. Buradaki çalışamayacak durumda olanların dişında kalan herkesin, kapitalizmin yedek iş gücü ordusu olarak kabul edildiğini iddia eden Foucault, 
bunun yeni iktidar taktiğinin gerçek yüzünü gösteren, önemli bir ayrıntı olduğunu iddia eder (Foucault, 1970b: 83).

Deliliğin Modern Çăg'da ele alınış biçimiyle ilgili olarak Foucault tarafından ele alınan son husus; daha öncede de kısmen değinildiği gibi kapatma olgusunun bilim ile eklemlenmesinden kaynaklanan tedavi yöntemleri ile ilgilidir. Bu tedavi yöntemlerinde, dönemin bilimsel işleyişine uygun olarak, psikiyatri kliniklerinde uygulanan tüm iyileştirici uygulamalar aslında insanları normalleştirme fonksiyonuna tabi tutar. Bu uygulamalar, bir zamanlar bilgelik misyonu yüklenen deliye sınır çizmedir. Bu haliyle, delilerin tedavi edilmeye çalışıldığı bu yeni tip kapatma evleri, iktidarın en büyük aygıtlarındandır (Foucault, 1977b: 157). Klasik dönemde aklın delilik üzerinde uyguladı̆̆ iktidar, şimdi bu psikiyatri klinikleri vasıtasıyla doktorun delilere uyguladığı bir iktidara dönüşmüştür (Foucault, 1977b: 160). Kuruluş gayesinin ya da topluma lanse edilenin çok ötesinde, akıl hastalığı söz konusu olduğunda, herhangi bir semptom saptayamayan bu klinikler, incelediği kişilere sadece "sen delisin" şeklinde bir damga vurur (Foucault, 1973a: 118). Bu damgalama, sinıflandırma işlevinin bir gereği olarak, deli ile deli olmayan arasına çizilen sınırları daha da belirgin hale getirir. Toplum, iktidar eliyle normal ve deli olarak kategorize edilirken, bu ayrımı iktidar adına belirleyen kişi psikiyatrdır (Foucault, 1973b: 130).

On dokuzuncu yüzyılla birlikte hızlı bir biçimde ivme kazanan ve bireylerin gözlenmesini, kaydedilmesini, sınıflandırılmasını ve davranışlarının karşılaştırılması üzerinden analiz edilmesini esas alan psikiyatrik bilgi için diğer kapatma uygulamalarında da açık bir biçimde var olan bir yaklaşım söz konusudur. Bu yaklaşımda üzerinde iktidar uygulanan bireyler, bilginin zorunlu nesneleri olarak ele alınır (Foucault, 1974a: 251). Sadece deney ve gözleme müsait ampirik edimleri ile özdeşleştirilmeye çalışılan deli, hiçbir zaman gerçek bir hakikat sorgulamasına tabi tutulmadan, iktidar onu nasıl algılamak istiyorsa öyle ele alınmak zorunda olan bir nesne vazifesi görür. Bir şekilde, belli bir alana yönlendirmeye ve öz bilincini fark edebileceği alanlardan uzaklaştırılmaya çalışılan delilerin, Foucault açısından, bilgeliğin sözcüsü olduğu zamanlardan çok daha ilkel bir çerçeveye bu şekilde hapsedilmesi, her zaman ve şartta sorgulanmaya muhtaç bir durumdur. Böyle bir sorgulama sonucunda, bir dönemler Fransa'da çalıştığı bir psikiyatri hastanesindeki işinden ayrılan Foucault, (Foucault, 1982a: 102) çağcıl psikiyatrların, kendisini yoğun bir biçimde anti-psikiyatr olarak görmelerini ise psikiyatrinin sözde bir bilim olması ile ilişkilendirir. Nitekim kapatma sorunsalı üzerinden sadece var olan bir tarihe ve gelişime vurgu yaptı̆̆ için çağcıl psikiyatrlar tarafından çokça 
eleştirildiğini ifade eden Foucault için gerçek bir bilim, kendinin ortaya çıkışındaki en utanç verici ve çirkin hikâyeleri dahi içine sindirebilmelidir (Foucault, 1982b: 138). Hal böyleyken, zorlama metotlarla, psikiyatri kliniklerinde modernite adı altında konulan tanı ve sonrasında uygulanan tedavilerin dinsel bir vahiy gibi algılanması ve söz konusu yöntemlerin evrensel ilkeler olarak dikte ettirilmesi, sadece psikiyatri açısından değil; diğer insan bilimleri açısından da kabul edilemez. Çünkü bu bilimlerde ele alınan ana olgu insandır ve insan hem varlığı gereği hem de yaşadığı toplumsal yapının gereklerine göre şekillenen var oluşu ile her türden genelleştirme ve nesnelleştirme iddiasının çok ötesinde yerel unsurlara göre şekillenen bir varliktır.

Günümüz sosyal hizmetlerine, delilik ve tımarhanelerin gelişim öyküleri üzerinden bu şekilde 1şık tutmaya çalışan Foucault'nun, eleştirilerinde yer verdiği ve en az tımarhaneler kadar önemli gördüğü bir diğer kurum ise hastanelerdir. Tımarhanelerin ortaya çıkışı ile başlayıp bilimsellik iddiası sonucu akıl hastanelerine dönüşmesiyle sonuçlanan deliliğe ilişkin kapatma dispositifinin gelişim öyküsünü de içerisinde barındıran hastaneler, Foucault açısından özellikle insanı anlama çabalarının arttığı yirminci yüzyıl için mutlaka ele alınması ve doğru anlaşılması gereken kurumların başında gelir. Zira hastaneler sadece tımarhaneler gibi toplumdan tecrit edilmesi gereken belli bir kesim yerine tüm insanları ilgilendiren ve onun fiziksel ve ruhsal özellikleri bakımından da ayrıca iktidarın gözünden değerlendirildiği daha nüfuz arttırıcı yapıları ifade eder.

\section{Hastaneler}

Foucault, sosyal hizmet uygulamalarının en önemli kurumlardan olan hastanelere ait görüşlerini, Deliliğin Tarihi adlı eserinden iki yıl sonra kaleme aldığı Kliniğin Doğuşu adlı eserinde daha detaylı bir biçimde masaya yatırır. Önceki başlıkta da görüldüğü üzere hastalık olgusu ekseninde deliliğin dahi son tahlilde psikiyatri çalışmalarıyla birleştirildiği hastaneler, bireyin incelenmesine ilişkin dönemin karakteristik havasına uygun bir biçimde doğa bilimsel bir yaklaşım sergiler. Bu nedenle Deliliğin Tarihi adlı eserinde psikiyatri ekseninde tamamlanamayan insana ait görüşleri, Kliniğin Doğuşu adlı eseriyle birlikte daha geniş bir biçimde ele almaya çalışan Foucault, yine bu incelemelerinde kısmen çok eski dönemlere atıfta bulunsa da başlangıç noktası olarak Modern Çă̆' 1 esas alır. Bu nedenle hastanelerin eleştirilmesi modernitenin ana dayanağı olan akıl ve bilimsellik üzerinden yapılır. 
Foucault'ya göre modern tıbbın ve dolayısıyla günümüz hastanelerin doğum tarihi on sekizinci yüzyılın son yılları olsa da (Foucault, 1963: 10) bir organizasyon olarak kliniklerin varlığını çok eskiye götürmek mümkündür. Çünkü günümüz modern tıp algısının aksine klinik organizasyonu, tıpta birey olgusunun keşfedilmesiyle bağlantılı bir biçimde ortaya çıkmamıştır (Foucault, 1963: 85). Bu bağlamda, yeminiyle ünlü Hipokrat, ilk hastane uygulamalarının temsilcisi olarak karşımıza çıkarken, tıp alanı, bu ilk organizasyonlarda bir nevi sanat olarak algılanır. Genç insanlar tıp bilimini hastaların yatağında öğrenir, hastalara genellikle hekimin evinde bakılır ve öğrenciler hasta ziyaretlerinde sabah akşam öğretmenleri olan usta hekimlere eşlik ederek mesleğe başlar (Foucault, 1963: 82). Evrensel olmayan bu uygulamalar, günümüz anlayışından uzak bir biçimde, bilim yerine felsefeyi sürece dâhil eden Hipokrat'ın eseridir ve Hipokrat, bu haliyle, Foucault için tıp alanında gözlemi terk eden bir sistematiğin kurucusu olarak kabul edilir (Foucault, 1963: 82).

On sekizinci yüzyıla kadar özellikle çoğu üniversitelerde, belli kürsüler paralelinde, günümüz hastanelerine benzer somut birkaç örneğe rastlamak mümkün olsa da Foucault, bu kurumların detaylı bir tarihsel dökümünün günümüz kliniklerindeki iktidar etkilerini görmekte yeterli olamayacağını düşünür. Çünkü bu çabalar ya daha başlangıç aşamasında başarısızlıkla sonuçlanmış ya da askeri, ekonomik ve akademik kaygılarla dönemin ağırlıklı politikalarını destekleyici açık iktidar hamleleri olarak kalmıştır (Foucault, 1963: 84-86). Oysa on sekizinci yüzyıl itibariyle başlayan modern tıbbi alg1 ve bu algıya göre şekillenen kliniklerde durum tam tersidir. Burada hem iktidar diğer dönemlerde görülmediği kadar sinsidir hem de toplumun her ferdine bir şekilde sirayet etmiştir. İktidarın toplumda her bireye ulaşmasını sağlayan argümanların sayısı Modern Çă̆ itibariyle çoğalmış ve bu argümanlar rasyonelleşme gibi tehlikeli bir sınır içerisinde, insanın hem bedenini hem de ruhsal özelliklerini kucaklayıcı bir taktikle sunulmuştur.

Modern tıbbın başlangıcında bilgi ve iktidarın sıkı ilişkisine dayalı olarak, empirik temelli bir insan incelemesi ve bu inceleme sonucunda elde edilen verilerin, rasyonel ilkeler ışığında sistematik bir hale getirilmesi söz konusudur. Belli standartların yakalanmasını amaç edinen klinik çalışmalarda, ortaya konulan teşhis ve tedavi yöntemleri, klinikleri, bireyler üzerinde dolaylı bir biçimde uygulanmak istenen tahakkümün arenası haline getirir. Klinik uygulamaların tahakkümünü görmek adına, on sekizinci yüzyılın son çeyreğinde, Fransa'da Kraliyet Tıp Derneği'nin dönemin tıp fakültesi ile yaşamış olduğu çatışma iyi bir örnek oluşturur. Nitekim salgınlarla mücadele etmek için anketlerin yapılması, deneyler yapmak suretiyle elde edilen olgusal 
verilerin kıyaslanması ve son aşamada eldeki verilere göre talimat ve denetleme yapılmasını içeren bir dizi kararı fakülteye kabul ettiren dernek, bu yolla doğrudan bilimsel alana müdahil olma yoluna gider (Foucault, 1963: 49-51). Sonraki dönemlerde politik ideolojinin ve tıbbi teknolojinin arasındaki ilişki, birbirlerini gerektiren bir biçimde gelişimini bu ilk örnekten hareketle sürdürmeye devam eder (Foucault, 1963: 62).

Tüm bu gelişim süreci içerisinde delilikte olduğu gibi hastalık ve klinik uygulamaları üzerinden bilimsel nedenselliğin gerektirdiği biçimde hastalıkların somuta indirgenerek ele alınmasını yadırgayan Foucault, tıbbi algının kendisine çizmiş olduğu sınırların dışına çıkamaması ile birlikte beliren pratiklerin, ironik bir biçimde metafiziksel bir kabule dönüştügüünü düşünür. $\mathrm{Bu}$ kabullere en iyi örneği; insana has özellikler olan kaygı, tutum, sezgi vb. tamamen psişik faktörlerin işlenmeye çalışıldığı psikoloji bilimine ait araştırmalar oluşturur. Psikolojide insana has birçok konu doğa bilimci bir analiz ve dolayısıyla mekanik nedenselliğe bağlı bir açıklama modeli ile ele alınmaya çalışılır. Örneğin; ruhsal hastaların zihnini ve liflerini serinletmek için yapılan banyo uygulaması ve aksayan dolaşımı veya hayal dünyasını canlandırmak için hastaya kan verilmesi gibi tedavi yöntemleri aracılığıla psişik semptomların altında fiziksel nedenlerin yer aldığını iddia eden psikolojik çalışmaların tamamı, (Foucault, 1954: 90) bireye dair bir açıklama yapmak bir yana bilimin kullanılması vasitasıyla ve doktor marifetiyle uygulanan iktidar taktikleri olarak kayda geçer. Bireylerin ayrı ayrı ele alınması yerine ayn nedensellik ilkeleriyle benzer bir olgu biçiminde ele alınmaları, Foucault'yu hakikat bağlamında rahatsız ettiği gibi insanın onurunu zedeleyen bir yaklaşım olarak da nitelendirilir. Bu nedenle Foucault, Wilhelm Dilthey'de vücuda gelen anlayışa benzer bir biçimde saf "açıklama" nın yerine "anlama" yı ön plana alan bir modelin, insanı belirlemek adına daha uygun düşeceğini iddia eder (Foucault, 1954: 58-61).

Bilimselliğin hastalık dispositifi üzerinden bireye karşı takındığı tek düze tutumun sonucu olarak on sekizinci yüzyıla kadar "Neyiniz var?" şeklinde hastalara sorulan soru, bu dönemde modern tıbbın bilimselleşmesinin gereği olarak, "Nereniz ağırıyor?" gibi daha somut ve sınırlı bir soruya dönüşür (Foucault, 1963: 18). Burada artık hastalık sadece fiziksel özelliklerden hareketle tanımlanmak istenir. Yine insanlık tarihinde büyük toplumsal değişimlere ve yıkımlara neden olan salgınlar noktasında da bu bilimsellik iddialarının ağırlıklı olarak kullanıldığı görülür. Öyle ki, politik bilinçle beraber bir hastalığın salgın olarak nitelendirilmesi için matematiksel bir çoğunluğun arandığ yeni tip teşhislerde, salgınla mücadele adı altında diğer bir iktidar aygıtı olan kolluk 
kuvvetlerinden de azami derecede yararlanılmaya çalış1lır (Foucault, 1963: 4446). Tüm bu uygulama değişimi ve değişim esnasında sürece dâhil edilen kolluk kuvvetleri ya da hasta hakları gibi yeni argümanlar, politik ideolojinin gerekleri ile yeni tıbbi teknolojilerin arasında kökü derinlerde olan bir yakınlık ve uyum olduğunu gösterir (Foucault, 1963: 62-63). Bu yakınlığın paralelinde tıbbi söylemin, bugün ahlaki açmazlar şeklinde de nitelendirilecek bir takım uygulamalara da imza atması, modern tıbbın daha kuruluş aşamasında eleştirilmesi için yeterlidir. Bu ahlaki açmazlardan Foucault'yu en rahatsız edenlerden biri, Fransız Devrimi sirasında yoksul hastaların, zenginler tarafından kurulan fonlar aracılığıyla tedavi edilmeleridir. Herkes tarafından bilinen hayırseverlik algısının tersine Foucault'ya göre yoksul bedeneler üzerinden iktidarın varlığını sürdürdüğü bu uygulamada, yoksul hasta aslında kendisini tıbbi anlamda bir öğretme sürecinin nesnesini olarak sunduğunun farkında değildir. Zira bu sürecin sonunda, aslında üst sınıftan bireylerin benzer hastalıklara maruz kaldığında kolaylıkla tedavi edilebileceği yöntemler geliştirilmeye çalışılır (Foucault, 1963: 115-117). Buradan hareketle, modern tıp uygulamalarındaki bilimsel çerçevenin, bireye sınır çizmeye çalıştığı kadar onu belli iktidar odaklarına hizmet etmeye mecbur bıraktığı da aşikârdır.

Hastalıkların modern tıp tarafından incelenmesinde bir diğer önemli nokta, nesnellik bağlamında vazgeçilmez ilkeler olarak kabul edilen belirti ve semptomlarla yakından ilişkilidir. Burada nesnellik bağlamında öncelikle hastalıklarla ilgili belirtilerin genelleştirici özelliklerine vurgu yapan Foucault, böylesi bir uygulamanın temelinde bulunan empirik usullere dayalı indirgemeci tutumu, Étienne Bonnot de Condillac'in görüşleri etrafında eleştirir (Foucault, 1963: 126). Condillac'ın "Her semptom belirtidir; ama her belirti semptom değildir." ilkesinden hareketle, ortaya konulan temel ayrımın dahi gerçekliği ifade etmede var olan indirgemeci tutumu değiştiremediğini iddia eden Foucault, bu bilimsel incelemelerin hakikate ulaşmada doğuracağı sıkıntıları ele almayı bir zorunluluk olarak görür (Foucault, 1963: 125-126). İster semptom isterse bir belirti olsun, var olan bir bulgunun, bedenler üzerinde meydana gelişine göre ön görülen sonuçlar açısından nesnel kriterlere uygunluğunun ortaya konulmaya çalışılması, günümüzde nesnellik kriteri olarak görülmekten oldukça uzak bir biçimde, daha çok olasılıklar üzerinden belli kurgulamaların yapıldığı bir faaliyet alanının resmini ortaya çıkarır. Burada bir nesne olarak ele alınan insanın bütünsel yapısına uygun bir biçimde, tüm yönlerini belirleyecek özsel bir hakikat unsuru olmasından vazgeçilerek, (Foucault, 1963: 131) olasılıklara dayalı bir bilme edimi içerisinde sıkışan bir unsura dönüştürüldüğü görülür (Foucault, 1963: 140). Bu nedenle, hasta tanımlamalarında, nesnellik 
gereği benzer vakalardan hareketle insanın ele alınması, epistemik düzlemde bilginin kendi düzeyinde yeniden biçimlendirilmesi olarak değerlendirilebilir (Foucault, 1963: 170). İktidar ve bilginin hem teorik hem de pratik anlamda birbirine eklemlendiği modern tıbbın, insanı ele alış biçimi, ancak bu şekilde okunduğunda bir anlam kazanır.

Hastaneler üzerinden Foucault'nun eleştirilerine bir bütün olarak bakıldığında, özellikle on sekizinci yüzyılla birlikte başlayan modern tıbbın, hem bedeni ve nüfusu hem de organizmayı ve biyolojik süreçleri konu alan yeni etkinliklerle bir bilme iktidarı oluşturmaya çalıştığı açıktır. Çeşitli disipline edici ve düzene koyucu taktiklerin kullandığı modern tıp, bu anlamda, geçmişte açıkça karşılaşılan siyasal iktidar oyunları kadar büyük etki yaratabilecek türden bir baskı mekanizmasını ifade eder (Foucault, 1976b: 258). Bireyin yeniden tahakküm altına alınması için oluşturulan hastanelerde, elde edilecek deneyimlerin mümkün hale gelebilmesi için hastaneye ayrılmış alanın tamamen sil baştan düzenlenmesi, hastanelerin toplum nezdindeki bozuk sicilli yapısının yeniden tanımlanması ve son olarak yardım-deney ve yardım-bilgi arasında belli bir ilişkinin kurulması gerekmiştir (Foucault, 1963: 244). Yeni ilişki ağlarının bu şekilde belirlendiği ve genişletildiği modern kliniklerle birlikte, bir yandan insan bir bilim nesnesi haline dönüştürülürken öte yandan iktidar ölüm söylemi üzerinden kurguladığı gizli tahakküm projesini hayata geçirmektedir. Yani modern hastanelerin kuruluş safhasında, Batı insanı, kendi kendini bilimsel yolla ifade edebilmek için kendi yokluğu olan ölümü modern tıbbın temeline bilerek ve isteyerek yerleştirmiştir (Foucault, 1963: 244).

Sonuç olarak, hastaneler üzerinden ortaya koyduğu bu görüşleriyle Foucault, sağlık ve sağlık hizmetleri bağlamında yirminci yüzyılda çok az sosyal bilimciye nasip olacak bir düşünce şekillenmesine ve etkiye neden olmuştur (Petersen, 2012: 7). Hasta haklarının güvence altına alınmasından, kliniklerdeki hastaya yaklaşım biçimlerine kadar geniş ölçekli ve sağlık sektöründeki her kesiminin yararlanmasına olanak sağlayan Foucaultcu bu etki, özellikle halk sağlığı gibi bazı alanların da günümüz açısından yeniden anlamlandırılmasında fazlasıyla yol gösterici olmuştur. Nitekim Foucault'nun eleştirileri sonrası modern hastanelerde "kamu yararı" veya "bireysel iyilik" olarak sunulan sayısız emir ve uygulamanın altında yatan gerçek olgunun iktidar olduğu çok geçmeden anlaşılmıştır (Petersen, 2012: 12).

Kapatma eylemi ve disiplin dispositifleri üzerinden hastanelerle ilgili eleştirilerinin ardından, Foucault, aynı dispositifler üzerinden sosyal hizmet alanında bir diğer önemli kurum olan hapishanelere ilişkin de benzer 
argümanlardan faydalanarak daha güçlü eleştirilerde bulunur. Özellikle modern iktidarın bireyleri imal eden disiplinleri kullanarak, kendisini gizlerken etkilerini daha da arttırdığı hapishaneler, tımarhane ve hastane örneklerinden daha kompleks bir ilişkiler ağını bireye dayatır. Üstelik bu ilişkiler ağında, tımarhane ve hastanelerde bir şekilde perde arkasında rol alan ceza ve hukuk sistemleri gibi bazı düzenleyici faktörler, hapishaneler söz konusu olduğunda, iktidar tarafından daha etkin bir silaha dönüştürülür.

\section{Hapishaneler}

Foucault'nun kapatma dispositifinden hareketle tımarhaneler ve hastanelerden sonra ele aldığı bir değer kurum hapishanelerdir. Genel itibariyle soybilim çalışmalarının ilkini oluşturan Hapishanenin Doğuşu adlı eserinde bahsettiği bu kurumları, hastane ve tımarhane örneklerinin ele alındı̆̆ eserlerinden farklı bir tarzda kaleme alan Foucault, bu şekilde iktidarın çok yönlülüğünü ve pratikler üzerindeki etkilerini daha derinlemesine aktarmaya çalışır. Foucault, Hapishanenin Doğuşu adlı eserinde hapishaneleri ele alırken, hastaneleri incelediği Kliniğin Doğuşu adlı eserine benzer bir biçimde, Rönesans ve Klasik döneme ait değerlendirmelere çok fazla yer vermemiş ve Antik Çă̆ ve Orta Çağ' da da örnekleri bulunmasına rağmen hapishanelere ilişkin tarihsel incelemelerini kasıtlı bir biçimde Modern Çağ ile başlatmıştır. Bu başlangıç, günümüz hapishanelerinin ortaya çıkışında dönemin rasyonalite sistemlerinin ve bu sisteme göre işleyen programların, bireyleri nasıl bir iktidar aracına dönüştürdüğünü göstermesi bakımından özenle seçilen bir zaman aralığını ifade eder. Zira Foucault açsısından karmaşık bir disiplin etme sürecinin işlediği modern hapishanelerin, bu haliyle, Modern Çă̆ öncesi benzerlerinin var olduğunun düşünülmesi imkânsizdır (Foucault, 1981: 265). Modern hapishaneler kullandığı iktidar teknolojileri ve hukuk sistemi açısından sil baştan düzenlenmiş ve modern çağla birlikte farklı bir ceza sistemi kullanan eşi benzeri olmayan yeni kurumsal yapılara dönüşmüştür.

Modern hapishanelerin bu yenilikçi ruhu ve tarihte var olan diğer cezalandırma ve kapatma kurumlarına benzememesinin ilk nedeni; bireylere uygulanan modern disiplin etme biçiminin eski disiplin etme biçiminden farklı olmasıdır. Foucault tarafından abluka-disiplin ve mekanizma-disiplin şeklinde adlandırılan bu disiplinlerden ilki, eski dönem hapishanelerinde kullanılan disipline karşılık gelirken, ikincisi modern hapishanelerde kullanılan disiplin biçimini ifade eder (Foucault, 1974b: 308). Hapishanelerde uygulanan bu iki farklı disiplin biçimi, söz konusu kurumun tarihsel incelemesine etki edecek kadar derin bir farklılığa neden olur. Dolayısıyla Foucault'ya göre günümüzde bu farklı disiplin biçimlerini göz ardı ederek, hapishaneler için yapılan tüm 
tanımlamalar ve değerlendirmeler geçersizdir ve birer yalandan ibarettir (Foucault, 1975b: 24). Hapishanelerin suçlulardan oluşan bir hurdalık olduğu ve bu hurdalığın sakıncalarının kullandıkça ortaya çıktığı yönündeki kabule dayalı olarak, sürekli reform isteyen bir kurum olması gerektiğini söyleyen bu yalancı açıklamalara rağmen hapishanelerle ilgili mevcut metinler, programlar ve niyet bildirimlerinin açıç̧a ortada bulunduğunu söyleyen Foucault, bu kurumların başından beri okul, kışla ve hastaneler gibi insanı dönüştüren mükemmel bir iktidar aygıtı olduğu kanaatini taşır (Foucault, 1975b: 24). Hal böyleyken, tarihsel olarak kapatma eylemelerinde hapishane adı altında var olan her kurumun aynı değerlendirilmesi ve birbirinin devamı olan yapılar şeklinde aktarılması mümkün değildir. Özellikle modern dönem öncesi ve sonrası olmak üzere uygulanan disiplin farklılıklarına göre ortaya çıkan iki farklı kurumsal yapı söz konusudur.

Disiplin etme biçimleri bakımından farklılaşan hapishane yapılarından hareketle, ilk olarak kullanılan abluka-disiplin temelli hapishanelerde genellikle kapatma dispositifi ekseninde, topluma aykırı tiplerin (suçlular, deliler, hastalar, kimsesizler, vb.) dışlanmasını ya da belli biçimde farklılaşan bireylerin toplumdan tecrit edilmesini esas alan açık bir iktidar taktiği ortaya konulurken, modern hapishanelerde sıradan hale gelen ve gizli iktidar taktiği olan bireyleri cezalandırmanın, bu eski örneklerde hiç bulunmadığını söylemek mümkündür. Örneğin, bugünkü hapishane mantığının olmadığı Orta Çağ'da, pratik anlamda kullanılan hücreler, Foucault için sadece mahkeme bekleme odaları olarak kullanılır. Ölüme gönderilecek olanlar, ölümü kefaretle satın almak için bekletilenler veya başka tarzda ceza kesilecek mahkûmlar burada geçici bir süreliğine misafir edilir (Foucault, 1972: 105). Herhangi bir cezalandırma mantığının olmadığı bu uygulamalar, Orta Çağ'da kullanılan diğer kapatma teknikleriyle de paralellik gösterir.

Orta Çăğ'dan Modern Çağ'a geçiş sürecinde yani Rönesans ve Klasik Çağ' da ise abluka-disiplinin etkisini kısmen kaybettiği ve mekanizma-disiplinin ortaya çıkışına zemin hazırlayacak uygulamaların bir bir hayata geçirildiği görülür. Bu uygulamalarda, Avrupa genelinde değişen siyasal yapıların büyük bir etkisi vardır. Orta Çağ'da dine dayalı bir biçimde, Tanrı'nın yeryüzündeki temsilcisi ya da feodal yapının kurucu şöhretini taşıyan birisi olarak nitelendirilen hükümdarların babacan bir tavır sergiledikleri yerde, Orta Çă̆ sonrası dönemler için siyasi yapıların şekillenmesinde devletin sürekliliği ve özgül ağırlığı daha büyük bir önem kazanır. Devlet artık kendisi için vardır ve ne kilise ne de hükümdar devletin bu kendinden varlığının önüne geçemez (Foucault, 1979: 7). Devletin siyasal yapı içerisinde öncelikli konuma gelmesiyle 
birlikte "devlet aklı" denilen bu güç, uzunca bir süre hukuksal süreçlere oranla daha üstün bir konuma yerleştirilir. Bu doğrultuda, özellikle on altıncı ve on yedinci yüzyıllarda, devlet aklının sınırsızlığına tam bir inanış söz konusuyken, onun dışında kalan siyasal olguların tamamı, bir şekilde sınırlı tutulmaya çalışılır (Foucault, 1979: 11). Orta Çağ ile Modern Çă̆ arası siyasal yapıda meydan gelen bu büyük mantıksal değişim, her alanda olduğu gibi ceza ve hukuk sistemlerinde de büyük bir değişime neden olur ve esasen modern iktidarın mekanik-disipline evirilmesini sağlayacak yol, böylelikle, Klasik Çă̆ itibariyle açılmış olur.

Klasik çağın son dönemlerinde devlet aklı fikri ve bu fikre istinaden tam olarak oluşturulamayan siyasal ve hukuksal yapı, iktidardakiler ve muhalifler arasında uzunca süren çekişmelerden sonra muhaliflerin başarılarıly sonuçlanır. Devlet aklına karşı yaklaşık iki asır süren mücadelenin ardından hukuk, hukuki düşünme, hukuk kuralları ve hukuki yaptırımlara başvurulması gibi birçok çağcıl kavram siyaset alanında temellendirilmeye başlanır (Foucault, 1979: 11). Tabi bu temellendirme günümüz açısından oldukça ilkel bir nitelik arz etmesinin yanı sıra henüz insanı özünde değerli bir varlık olarak kabul etmenin çok gerisindedir. Mekanizma-disiplinin başlangıcını da ifade eden bu süreçte, ilk olarak, iktidarın bedenler üzerinde en dehşet verici bir biçimde tahakkümünü uyguladığı halka açık cezalandırma yöntemleri sahneye çıkar. Nitekim Foucault'nun, konuyla ilgili kaleme aldığı Hapishanenin Doğuşu adlı eserinin hemen ilk sayfasında, halka açık olarak bedenler üzerinde uygulanan bu dehşet verici cezalandırma biçimini, tüm çıplaklığı ile ayrıntılı olarak gözler önüne sermesi, aslında, suçlunun bedeni üzerinde başlayıp, moderniteyle birlikte ruhsal özelliklerini dahi kapsayacak olan iktidar etkisini göstermek için seçilen kasıtlı bir örnektir. Söz konusu bu örnekte, babasını öldüren bir suçlunun iki elinde yanar halde bulunan birer meşale taşıyarak idam edileceği meydana gelmesi ve suçunu herkesin önünde itiraf etmeye mecbur bırakılması sonrasında çırılçıplak soyundurulmuş halde darağacına çekilmesi ve bütün uzuvları kesilerek dehşet verici bir biçimde öldürülmesi ayrıntılı bir biçimde aktarılır (Foucault, 1974b: 33). Foucault'nun hapishanelerin gelişim serüvenini anlattığ bu eserin ilk sayfalarında, beden üzerindeki akıl almaz işkencelere dayalı bu cezalandırmayı sunmak istemesi, modern iktidarın yükseldiği temel dayanak noktalarına ve mekanizma-disiplinin ne denli kabul edilemez bir olgu olduğuna dair okuyucuyu daha başlangıçta ikna etmek istemesinden kaynaklanır. Zira bedenler üzerinde başlayan bu akıl almaz ve dehşet verici uygulama, sonraki dönemlerde modern iktidarın acımasızlığının anlaşılması için bir anahtar işlevi taşır. Nitekim mekanizma-disiplinin bedenler üzerindeki bu akıl almaz işkence 
metotları, on sekizinci yüzyılda doruğa ulaşıp, tüm Avrupa kentlerinde seyirlik bir uygulama olarak yaygınlaşır. Üstelik bilimsel bilginin pratikte hayatımızı kolaylaştırmak için kullanıma sunduğu teknik bilgilerden, suçlu bireylere azap çektirme adına faydalanılmaya dahi başlanır. Yaklaşık bir asırı aşkın bir süre Avrupa'nın çeşitli ülkelerinde kullanılan giyotin, işte böyle bir faydalanmanın soncunda ortaya çıkar. Giyotin, hakikat bağlamında, mantık ve deneyin bilimselliğini değil; eskiden uygulanan azaplı ölümleri kanıtlamak için kullanılır ki, bu beden üzerinde bilimselliğin ne denli yıkıcı bir etkisi olduğunu gösteren en keskin örneklerden biridir (Foucault, 1974b: 46).

On dokuzuncu yüzyılın başlarında bedene yönelik azap çektirme uygulamaları ciddi bir biçimde Batı dünyasında sorgulanmaya başlar. Bu sorgulama paralelinde önce halka açık cezalandırmalar sona erdirilir sonra da giyotin vasıtasıyla gerçekleştirilen ani ölümlerle azabın en az dereceye düşürülmesine karar verilir. Böylelikle cezalandırma seyirlik bir unsur olmaktan çıkartılır ve azap çekmenin ortadan kalkması, Avrupa genelinde on dokuzuncu yüzyıl ortalarında yerleşik bir kabule dönüşür (Foucault, 1974b: 47). Bu dönemle birlikte daha önce giyotin uygulamasında cezalandırmanın hızlı ve etkin yapılması için kullanılan bilimsellik algısı, bu kez beden yerine ruha ceza verme gibi insanı daha derinden etkileyen bir cezalandırma sisteminin inşası için kullanılır (Foucault, 1974b: 50). Ruhun ceza sistemleri içine dâhil edilmesiyle birlikte, kanitlanabilir ve rasyonel bilimsel bilginin hukuki uygulama alanlarına niçin ve nasıl sızdığını araştırmak, bu anlamda, günümüz hapishanelerin gerçekte ne olduğu sorusunun cevaplanabileceği düşünsel malzemeleri bulmayı kolaylaştırır (Foucault, 1974b: 60). Bilgi ve iktidarın birbiriyle sıkı bir ilişki içerisine girdiği bu dönem itibariyle iktidar etkilerini yansıtan bilimsel veriler; ekonomik, ahlaki ve toplumsal diğer kabullerle de paralellik arz eden bir biçimde, cezalandırma ve hukuk sistemine genel olarak iki şekilde eklemlenir. $\mathrm{Bu}$ eklemlenmenin ilki; doğa bilimsel yöntemleri kullanan sosyal bilimler alanındaki insana ait olgusal değerlendirmelerin, suçu ve suçluyu ortaya çıkarmak maksadıyla kovuşturma aşamasında kullanılmasıdır. İkinci ve daha önemli olan eklemlenme ise cezalandırma safhasında uygulanan infaz ve islah etme çalışmaları ile ilgilidir. Foucault açısından insan ve insanlığa saygı duymak adına çağın koşullarına göre beliren ihtiyaçların şekillendirdiği bu bilimsel eklemlenmelerin, nasıl sonraları bir sürü garip ve anlaşılması zor sorgulama tekniklerine dönüştüğünü anlamak son derece önemlidir (Foucault, 1974b: 127). Çünkü bu eklemlenmeler, iktidarın karmaşık toplumsal ilişkiler ağında, kendini gizlemek adına bulduğu etkin çözümlerdir ve hem cezalandırmanın 
maliyetlerini düşüren hem de iktidarın etkilerini her bireye sirayet edecek kadar yaygınlaştıran uygulamalardır (Foucault, 1974b: 135-136).

Bilimsellik algısının yeni ceza ve hukuk sistemleri içerisine dâhil olmasıyla birlikte, mekanizma-disiplin etkin bir biçimde tüm ceza uygulamaların temeline yerleşmiş olur. Yeni cezalandırma sisteminde suçluların belli kriterlere göre sınıflandırılmaya tabi tutulması, aslında onları birer nesne olarak değerlendirmek anlamına gelir ve bilimsel bilgi bu sınıflandırmada temel dayanak noktasını oluşturur. Öte yandan ıslah etme programları çerçevesinde daha karmaşık ve etkili bir alan olarak düzenlenmesi gereken hapishane, bu kez iktidar eliyle üretime katkı sağlanan ve bireylerin kendi özlerine ruhen geri dönüşü yaşadıkları bir mekân olarak tasarlanır (Foucault, 1974b: 192). Önceleri iktidarın varlığını hissettirdiği ölüm ve tehdit fonksiyonlarının yerini, bu kez, çağdaş disiplin etme teknikleri aracılığıyla, yaşatma ya da topluma kazandırma fonksiyonları alır (Foucault, 1976a: 103). Bir zamanlar hükümdarın malı olarak görülen ve hükümdara tabi bir nesne olarak algılanan mahkûm ve bedeni, ıslahı amaçlayan yeni ceza sistemleri ile birlikte, tüm toplum için ortak ve ekonomik olarak yararlı bir nesne haline gelir (Foucault, 1974b: 164). Bedenler artık yeni düzen arayışı içerisinde bir değeri bulunan ve herhangi bir aşamada kullanılmaya ya da daha doğru bir ifadeyle değerlendirilmeye hazır olgulara evrilir. Dolayısıyla yaşatma ve topluma yeniden kazandırma fonksiyonlarını icra eden bu yeni iktidarın adı da artık biyo-iktidar olarak anılır. Bu anlamda, biyo-iktidar, önceki iktidar yapılarından farklı olarak, bilim eksenli bir tabanda; niteleyen, ölçen, değerlendiren, hiyerarşiye sokan ve normlar çerçevesinde bireylerin dağıtımını yapan bir mekanizmadır (Foucault, 1976a: 106). Bundan böyle bilim ve bilimsel bilgi, biyoiktidara hizmet etmek adına, ceza ve hukuk sistemlerini yeni bir olgusal düzlemde, yeni kriterlere dayalı olarak işletmek zorundadır.

Mekanizma disiplinin cezalandırma sistemlerinde kullandığı ve günümüz modern hapishanelerinin de ilk örneği olan Panoptikon², tam olarak böyle bir cezalandırma sistemiyle eşgüdüm içerisinde oluşturulur. Faydacı bir düşünür olmakla beraber iyi bir hukukçu ve reformist bir toplum araştırmacısı olarak da nitelendirilen Jeremy Bentham tarafından 1785 yılında geliştirilen ve Panoptikon adı verilen bu çok gelişmiş hapishane, bilim eliyle mükemmel bir kurumsal yapının tasvir edilmesini içerir. Kelime anlamı bütünün gözlemlenmesi olan Panoptikon, iç içe geçmiş halkalardan oluşan bir binadır ve

${ }^{2}$ Bu konuda, daha geniş bilgi sahibi olmak için J. Bentham'ın çevirisi yapılan ve aynı adı taşıyan eserine bakılabilir. [Bknz. Jeremy Bentham, “Panoptikon: Gözün İktidarı”, (çev. Barış Çoban, Zeynep Özarslan), Su Yayınları, İstanbul 2008.] 
bu binanın tam ortasında sadece bir adet gözetleme kulesi bulunur. Mahkûmların hücreleri bu gözetleme kulesinden rahatlıkla görülebilecek şekilde sıra sıra dizilir. Bir mahkûm kendisini ne kadar saklamaya çalışırsa çalışsın, hapishanenin mimari yapısı vasıtasıyla oluşturulmuş ışıklandırma düzeneği öyle mükemmeldir ki, mahkûmun gölgesi dahi rahatlıkla kuleden görülebilir. Sürekli gözetim ve denetim altında tutulmakta olduğunu bilen mahkûm, zaman içerisinde kendisini kuledeki gardiyanın gözüyle görmeye ve o gözün beklentileri doğrultusunda hareket etmeye başlar. $\mathrm{O}$ kadar $\mathrm{ki}$, artık kulede bir gardiyan olup olmadığı önemsizleşir ve mahkûm hapishanenin gözünü ve mevcut otoritenin bakış açısını içselleştirmiş olur (Foucault, 1974b: 295-297). Tam anlamiyla denekleri insanlar olan modern iktidarın, bir tür büyük laboratuvarı olarak düşünülen Panoptikon, insan tutumları üzerinde daha etkin olmayı sağladığı gibi toplumun diğer kapatma eylemi amaçlanan kurumları (okul, hastane, kışla vb.) için de uygulanabilir örnekler taşıyan bir aygıttır (Foucault, 1974b: 302-303). Panoptikon, çok yönlü ve karmaş1k toplumsal ilişkilerin görüldüğü Modern Çağ' da gözetleme sorunlarını çözmeye en uygun iktidar teknolojisidir (Foucault, 1977c: 87).

Modern cezalandırma sistemleri ve uygulamalarında görülen Panoptikon benzeri kurumsal yapılar, bilimin iktidarla sıkı bir işbirliği içerisinde olduğunu gösteren mekânlar olmanın yanı sıra toplumsal ve ekonomik faaliyetlerin de aynı iktidar eliyle süreç içerisinde değerlendirmeye tabi tutulduğu mekânları ifade eder. Eski dönem kapatma uygulamalarında bireyleri dışlamak amacıyla tecrit görevi gören hapishaneler, modern dönemde, ekonomik gerekçelerle her bireyi toplumsal sürece dâhil etmeye çalışan ve bu amaçla onları belli normlara göre şekillendiren kurumlara dönüşür (Foucault, 1974a: 245). Böylelikle bir eğitim aracı haline dönüştürülmeye çalışan suçlu insanlar, burada iktidarın istediği biçimde bir biçimlendirmeye tabi tutulur ve söz konusu bu biçimlendirmede çeşitli nesnelleştirme kriterleri kullanılır (Foucault, 1974b: 164). Her suçun fiziksel ve manevi etkilerle tedavi edilebilir olduğuna inanılan yeni nesnelleştirme kriterlerinde, toplumsal olarak yeniden değer kazandırılmak istenen insanın, aslında iktidar eliyle yeniden dizayn edilmesi amaçlanır. Burada modern özne adı altında değerli kabul edildiği ilan edinen insan, aslında iktidara boyun eğdirilen bir nesne olarak, kural ve emirlere itaat eden ve üzerinde inşa edilen koca otoritenin perdelendiği bir birey olarak tasarlanır (Foucault, 1974b: 200-201). Foucault için 1slah etmeyi ve bireyleri iktidarın ön gördüğü bir biçimde tek tip bireyler olarak topluma geri kazandırmayı amaçlayan bu yapılara en iyi örneği, 22 Ocak 1840 yılında Fransa'da bir ılah evi olarak kurulan Mettray oluşturur. Altı ve yirmi bir yaş 
arası bireylerin (çocuk ve gençlerin) kabul edildiği bu yapı, içerisinde kalan bireylerin davranışlarına karşı en yoğun bastırma teknolojilerinin uygulandığı bir tür hapishanedir. Sıkı bir hiyerarşiye göre sınıflandırılan bireylerin başında bulunan görevlilerin ve uygulanan metotların çeşitliliği düşünüldüğünde, hemen hemen tüm modern kapatma kurumlarında rastlanan uygulamaların bir benzerine Mettray'de rastlamak mümkündür. $\mathrm{Bu}$ haliyle, bireyleri nesnelleştirme metotlarına uygun olarak, tek düze biçimselleştirmenin en bariz örneklerinden olan Mettray, daha erken yaşlarda bireylerin iktidara nasıl boyun eğdirilerek, onun istekleri etrafında davranışlarının şekillendirildiğini gösteren ibretlik bir mekândır.

Foucault'nun, özelde Panoptikon ve Mettray gibi tasarımlarla irdelemeye çalıştı̆̆ı, hapishanelere ilişkin genel kanaati, modern kapitalist anlayışı da kapsayacak bir biçimde, bu türden kapatma mekanizmaların modern bir fabrika gibi iktidarın isteklerine boyun eğen bireyler yetiştirmeye çalışan kurumlar olduğu fikri üzerinde yoğunlaşır. Topluma aykırı ya da suçlu diye nitelendirilen bireylerin, iktidarın öngördüğü bir biçimde tek tipleştirildiği ve aynı standartlarla tekrar topluma kazandırılmaya çalışıldığı kurumları anımsatan hapishaneler için Foucault'nun hapishane-fabrika ütopyası diye adlandırdığg bir kavram kullandığı görülür. Buna göre modern kapatma usulleri ve infazların gerçekleştirildiği mekânların tamamında amaçlanan şey; hümanist yaklaşımların ön gördüğü değerli özne fikrinin yerine iktidarın çeşitli hilelerle kendisine boyun eğdirdiği bireyleri disipline etmektir ve bunu yaparken de kendisini görünmez kılmaktır (Foucault, 1974a: 242-244). Ancak gerek bilimsellik gerekse ekonomik ve toplumsal koşulların ortaya çıkardığı yeni gelişmelerin doğru bir strateji ile bir arada kullanılarak geliştirildiği hapishaneler, yirminci yüzyılın ortalarına gelindiğinde, iktidarın istediği biçimde bir algılamaya neden olamamıştır. Bunun için hapishane-fabrika ütopyası çökmüş ve kuruluş felsefesindeki temel mantığa aykırı bir biçimde, hapishanelere giren kişiler, çıtı̆̆ında daha çok suça meyilli bireyler haline gelmişlerdir (Foucault, 1975b: 26). Foucault'ya göre bir üretim olsa bile bu iktidarın tasarladığı türen nesnelleştirilmiş bireylerin aksine tamamen profesyonelleşmiş suçluları içeren bireyler şeklinde tezahür etmiştir. Modern hapishane kurgusu ne yazık ki, suça eğilimli kişilerin imalathanesi haline gelirken, bu türden kişiler, yine görünmek istemediği toplumsal zeminler için iktidarın kullanımına açık malzemeler olmuşlardır (Foucault, 1976c: 82-83).

Hapishaneler hakkındaki tüm açıklamaları dikkate alındığında, Foucault için genel bir sslah etme veya toplumun geneli için menfaatlerin korunduğu bir kurumsal yapıdan söz etmek oldukça zordur. Ne bilimselliğin hukuk 
sistemlerinde kullanışı ne de infaz sürecinde bilimsellikten yararlanılarak insan onuru korumak adına daha iyi bir kamusal alan oluşturmak için düzenlenen hapishaneler, iktidarın her yere nüfuz etmesini engelleyememiştir. Aksine tüm uygulamalar zamanla iktidarın suçlular dahi toplumun her ferdine bir şekilde ulaşmaya çalışan vazgeçilemez bir olgu olduğunu bir kez daha kanıtlamıştır. Yirminci yüzyılın sonu itibariyle modern hapishanelerin ardında yatan ve insanın onurunu zedelemeden insanlığın yararına sunulduğu iddia edilen hapishane vb. kurumların bugün tüm çıplaklığıyla anlaşılır kılınması, konuyla yakından ilgilenen herkesin üzerinde durması gereken önemli bir husustur. Zira bu türen kurumların üzerine söylenecek sözler ve uygulamalardan doğan aksaklıklardan alınacak dersler hiçbir zaman bitmeyecektir.

\section{Sonuç}

Sosyal hizmet alanı, henüz gelişmekte olan yeni bir alan olarak, Michel Foucault'nun görüsslerinden hem teorik hem de pratik anlamda istifade edilebilecek alanların başında gelir. Özellikle burada ele alınan tımarhane, hastane ve hapishane örneklerinden hareketle, eserlerinde sık sık bahsi geçen sosyal hizmetler alanında faaliyet gösteren diğer kurumlara ilişkin anekdotlar düşünüldüğünde, Fransız düşünürün engin bir düşünce dünyası sunduğu muhakkaktır. Çağın gereklerine göre bugün sosyal hizmet alanını ilgilendiren birçok kurumun ya da uygulamanın aksayan yönlerine ilişkin tarihsel analizlerin detaylı bir biçimde yapıldığı Foucault düşüncesinde, etik bir varlık olarak özünde barındırdığı değerlerin sürekli canlı tutulması arzu edilen insanın, kendisi dışındaki hiçbir oluşum ya da olguya tercih edilemeyecek kadar kıymetli bir varoluş misyonuna sahip olduğu görülür. Üstelik bu misyon gücünü bizzat insanın kendi açmazlarından ve karmaşık yapısından alır. Bu nedenle adı ve özelliği ne olursa olsun, herhangi bir üst oluşum ya da genelleştirici düşüncenin bir formül olarak insana etki etmesi ve onu sinırlandırması yadırganır.

Foucault felsefesinin çok yönlü ve insanın kendinden müteşekkil varlığını önemseyen düşüncelerinin, kendisi gibi düşünen diğer postmodern düşünülerle birlikte, sosyal hizmet alanında büyük zemin kaymalarına neden olduğu açıktır. 1960'lar ve 1970'lerde Foucault'nun da aralarında bulunduğu çağcıl düşünürlerin yoğun eleştirilerine maruz kalan geleneksel sosyal hizmet uygulamaları, ırkçılık karşıtı sosyal hizmet, çok kültürlü sosyal hizmet, baskı karşıtı sosyal hizmet, ayrımcılık karşıtı sosyal hizmet, feminist sosyal hizmet, Marksist sosyal hizmet ve radikal sosyal hizmet gibi birçok yeni yaklaşımın ortaya çıkışına şahitlik etmiştir (Özgür, 2010: 100). Bu yaklaşımlardan modern 
dünya tarafından meşrulaştırılan bir iktidar teknolojisini ve yönetim sanatını içerisinde barındıran eski sosyal hizmet uygulamalarının bir kenara atılmasını öngören baskı karşıtı sosyal hizmette, tek bir merkezden yönetilen ve uygulanan araştırma teknikleri yerine çağın postmodern anlayışına uygun bir biçimde yerel ve çok sesli bir uygulama alanı arzulanır ki, esasen bu uygulama alanının doğrudan fikir babası olarak karşımıza Foucault çıkar (Güldalı, 2018: 230). Bunun yanı sıra yine psikolojiyle doğrudan ilişkili mesleklere yönelttiği itirazlarla çok kültürlü sosyal hizmet uygulamalarına da doğrudan katkı sunan Foucault, geleneksel sosyal hizmet uygulamalarında görülen Batı kültürüne ait tekelleştirici yöntemleri, özne lehine çoğulcu bir faaliyete dönüştürmeyi arzu eder (Özgür, 2010: 92). Tüm bu yaklaşımların odağında bulunan ve insanı önemseyen sosyal hizmet anlayışlarını bir şekilde etkileyen düşünürün, feminist akımlarla ve Marksist ideolojiyle olan fikri münasebetleri de Foucault felsefesini tanıyanlar açısından malumdur. Dolayısıyla Foucault, gerek ele aldığı konular ve kurumlar gerekse felsefi düşüncesinde önemli bir yere sahip insan faktörüyle sosyal hizmet alanı için teorik zeminde eşine az rastlanır bir düşünürdür.

Foucault'nun teorik zeminde sosyal hizmet alanına yaptığı katkıların yanında, özellikle Hapishanenin Doğuşu adlı eserini kaleme aldığı ve soybilim çalışmalarının da başlangıcını ifade eden 1970'li yıllardan sonra pratik uygulamalar içerisinde de aktif bir rol aldığı görülür. Hatta bazı düşünürler soybilim çalışmalarındaki üslup ve inceleme tarzındaki değişikliği, Foucault'nun bizzat siyasi ve sosyal faaliyetlerdeki aktif rolleriyle doğrudan bağlantılı bir durum olarak yorumlar (Paras, 2006: 98). Foucault'nun siyasi ve sosyal faaliyetler bağlamında pratiğe ilişkin sosyal hizmet uygulamalarını ilgilendiren en önemli olay, hiç kuşkusuz, onun 1971 yılında, G.I.P adı ile bilinen Hapishaneler Üzerine Enformasyon Grubu'nun kurucuları arasında yer almasıdır (Eribon, 1992: 224). 1970 yılında Proleter Sol adlı Maocu hareketin dağıtılması sonrasında, bu harekete mensup birçok kişinin militan ilan edilerek hapse atılmasıyla başlayan süreçte, bu mahkûmların burada yaşadığı sorunları araştırmak maksadıyla, Jean Paul Sartre, Fransa'da benzer durumlarda da rastlanılan bir soruşturma komisyonu kurma fikriyle 1971'de Foucault'ya gelir ve Foucault bunu hiç tereddüt etmeden kabul eder. Ancak soruşturma adını eleştirilerine konu olan hukukçularla ilgili bir terim olduğu gerekçesiyle değiştirir ve yerine haberleşme kavramını kullanır. (Foucault, 1971: 101) Bu grup yapmış olduğu çalışmalara dönemin hapishaneleri üzerinde büyük bir etki uyandırır. Örneğin; bu hareket sonrası o zamana kadar yasak olan gündelik basin ve radyo kanallarının hapishanelere girmesine olanak tanınır (Foucault, 1971: 101). Hapishanelerde neler olup bittiği ile ilgili bu haberleşme grubunun 
ardından kısmen mahkumlar lehine ses getirici iyileşmeler olunca bu grubun devamı niteliğinde daha sonra G.I.S. (Sağlık Haberleşme Grubu), G.I.A. (Akıl Hastaneleri Üzerine Haberleşme Grubu) ve G.I.S.T.I (Göçmen İşçiler Haberleşme ve Dayanışma Grubu) adı altında farklı sosyal hizmet alanlarında faaliyet yürüten kurumlar adına benzer çalışmalar yapılır (Foucault, 1971: 101). Foucault'nun doğrudan kurucu ya da üyesi olarak bulunduğu bu gruplar dikkate alındığında, onun sadece moderniteyi eleştirmekle kalmadığı aynı zamanda bir sosyal hizmet mensubu faaliyetler icra ettiğini de söylemek mümkündür.

Tüm bu açıklamalar ışığında rahatlıkla denilebilir ki, Batı' da eserleri ve faaliyetleriyle sosyal hizmet alanında büyük yankı uyandıran Foucault'nun, ülkemizde de aynı çalışmaları yürüten tüm paydaşlar tarafından bilinmesi oldukça büyük bir önem taşımaktadır. Deliliğin Tarihi'ni kastederek, eserlerinin; psikiyatrlar, psikologlar, hastabakıcılar vb. kapatma olgusu içerisinde görev alan herkes tarafından okunmasını tavsiye eden Foucault'nun, (Foucault, 1974c: 148) bu bağlamda, ülkemiz sosyal hizmet alanındaki paydaşlara da doğrudan üç şekilde fayda sağlayacağı düşünülmektedir. Bu faydalardan ilki, Foucault aracılığıyla Batı' daki sosyal hizmet kurumlarının tarihsel gelişim serüvenlerinin detaylı bir biçimde öğrenilerek, bu bilgilerin, ülkemizdeki benzer kurumların gelişim öyküleriyle mukayese edilebilmesi olanağı yaratmasıdır. Bu türden bir mukayese, yapılan hizmetlerin aynı dönem içerisinde hangi kriterlere göre yapıldığı noktasında ipuçları verecek ve yapılan hizmetin kalitesini anlamaya yardımcı olacaktır. İkinci olarak, gelinen nokta itibariyle sosyal hizmet alanındaki güncel uygulamaların ardında yatan ve insanın her koşulda değerli olduğunu düşünen çağdaş anlayışların, daha iyi özümsenerek, uygulanabilirlik safhasındaki yaratıcılığa dâhil edilmesi mümkün olacaktır. Zira çağının beklentilerini, ihtiyaçlarını ve düşünce sistematiğini yansıtmayan hiçbir uygulamanın uzun soluklu olması mümkün değildir. Son olarak yine Batı dünyasındaki uygulamalarla Orta Doğu, Afrika ve Uzak Doğu'daki diğer medeniyetlerin uygulamaları arasındaki değerlendirmelere de eserlerinde yer veren düşünürün gözünden, Batı'nın kendi uygulamaları dışındaki sosyal hizmet faaliyetlerine nasıl bir açıdan baktığını görme şansı da yakalanabilir. Nitekim Japonya, İran, Cezayir vb. birçok ülkede çeşitli sebeplerle bulunan Foucault'nun, yerelselliği önemseyen bakış açısının zorunlu bir sonucu olarak, burada yaşayan toplumlara ait değerlendirmeleri de en az Batı'daki kurumsal yapılara ilişkin görüşleri kadar sarsıcıdır. 


\section{Kaynakça}

Doel, M. (2012). Social Work The Basics, New York: Routledge - Taylor \& Francis Group.

Duyan, V. (2003). "Sosyal Hizmetin işlev ve Rolleri". Toplum ve Sosyal Hizmet, 14 (2), 1-22.

Eribon, D. (1992). Michel Foucault, (trans. Betsy Wing), Massachusetts: Harvard University Press.

Foucault, M. (1954), Akıl Hastah̆̆ğ ve Psikoloji, (Çev.: Emre Bayoğlu), İstanbul: Ayrıntı Yayınları.

-- (1976c). "Bakış Açıları" (Çev.: Işık Ergüden), İktidarın Gözü, İstanbul: Ayrıntı Yayınları, 82-84.

(1979). Biyopolitikanın Doğuşu - College de France Dersleri 1978-1979, (Çev.: Alican Tayla), İstanbul: İstanbul Bilgi Üniversitesi Yayınları.

(1972). “Büyük Kapatılma” (Çev.: Işık Ergüden), Büyük

Kapatılma, İstanbul: Ayrıntı Yayınları, 103-115.

İstanbul: Ayrıntı Yayınları.

(1976a). Cinselliğin Tarihi, (Çev.: Hülya Uğur Tanrı̈ver),

(1970b). “Delilik ve Toplum” (Çev.: Işık Ergüden), Büyük Kapatılma, İstanbul: Ayrıntı Yayınları, 76-84.

(1978). “Delilik ve Toplum” (Çev.: Işık Ergüden), İktidarın

Gözü, İstanbul: Ayrıntı Yayınları, 210-233.

(1970a). "Delilik, Edebiyat, Toplum" (Çev.: Işık Ergüden),

Sonsuza Giden Dil, İstanbul: Ayrıntı Yayınları, 260-286.

İstanbul: İmge Kitabevi.

(1961). Deliliğin Tarihi, (Çev.: Mehmet Ali Kılıçbay),

(1973b). "Dünya Büyük Bir Tımarhanedir" (Çev.: Işık Ergüden), Büyük Kapatılma, İstanbul: Ayrıntı Yayınları, 129-131.

(1971). "G.I.P Manifestosu” (Çev.: Işık Ergüden), Büyük Kapatılma, İstanbul: Ayrıntı Yayınları, 100-102.

(1977b). "Göz Kamaştırıcı Hayvan: İktidar" (Çev.: Işık Ergüden), İktidarın Gözü, İstanbul: Ayrıntı Yayınları, 150-166.

(1982a). “Hakikat, İktidar ve Kendilik” (Çev.: Işık Ergüden), Özne ve İktidar, İstanbul: Ayrıntı Yayınları, 98-105.

(1974a). "Hakikat ve Hukuksal Biçimler" (Çev.: Işık Ergüden), Büyük Kapatılma, İstanbul: Ayrıntı Yayınları, 163-278. 
(1975b). "Hapishane Üzerine Söyleşi: Kitap ve Yöntemi"

(Çev.: Işık Ergüden), İktidarın Gözü, İstanbul: Ayrıntı Yayınları, 21-37.

(1974b). Hapishanenin Doğuşu - Gözetim Altında Tutmak ve

Cezalandırmak, (Çev.: Mehmet Ali Kılıçbay), İstanbul: İmge Kitabevi.

(1974c). “İktidar Mekanizmasında Hapishaneler ve

Tımarhaneler" (Çev.: Işık Ergüden), Büyük Kapatılma, İstanbul: Ayrıntı Yayınları, 144-149.

(1977a). “İktidar ve Bilgi” (Çev.: Işık Ergüden), İktidarın Gözü, İstanbul: Ayrıntı Yayınları, 167-184.

- (1977c). “İktidarın Gözü” (Çev.: Işık Ergüden), İktidarın

Gözü, İstanbul: Ayrıntı Yayınları, 85-105.

---- (1963). Kliniğin Doğuşu - Tıbbi Algının Arkeolojisi, (Çev.: Şule Ünsald1), Ankara: Epos Yayınları.

(1981). “Michel Foucault İle Söyleşi” (Çev.: Işık Ergüden), İktidarın Gözü, İstanbul: Ayrıntı Yayınları, 263-276.

(1973a). "Sonuç Yerine" (Çev.: Işık Ergüden), Büyük

Kapatılma, İstanbul: Ayrıntı Yayınları, 116-119.

--- (1982b). "Stephen Ringgins'le Söyleşi" (Çev.: Osman Akınhay), Özne ve İktidar, İstanbul: Ayrıntı Yayınları, 123-139.

-------- (1975a). “Tımarhaneler, Cinsellik, Hapishaneler” (Çev.: Işık Ergüden), İktidarın Gözü, İstanbul: Ayrıntı Yayınları, 47-60.

- (1976b), Toplumu Savunmak Gerekir, (Çev.: Şehsuvar Aktaş), İstanbul: Yapı Kredi Yayınları.

Güldalı, O. (2018), “Baskı Karşıtı Sosyal Hizmet: Modern Dünya-Sistemi Açısından Eleştirel Bir Değerlendirme", Toplum ve Sosyal Hizmet, 29 (1), 228-244.

Kirk, S. A. \& Reid, W. J. (2002). Science and Social Work A Critical Appraisal, New York: Columbia University Press.

Özgür, Ö. (2010), "Çok Kültürcü Sosyal Hizmet: Eleştirel Bir Bakış", Toplum ve Sosyal Hizmet, 21 (2), 89-104.

Paras, E. (2006), Foucault - Öznenin Yitiminden Yeniden Doğuşuna, (Çev.: Yunus Çetin), İstanbul: Kolektif Kitap.

Parrott, L. (2001). Social Work and Social Care, New York: Routledge - Taylor \& Francis Group. 
Petersen, A. (2012). "Foucault, Health and Healthcare", Graham Scambler (ed), Contemporary Theorists for Medical Sociology, New York: Routledge Taylor \& Francis Group, 7-19.

Santos, F. (2006). "Foucault and Social Sciences" (Translated by. Marta Ines Merajver), Sociedad (B. Aires), Vol. 1, Special Edition, http:/ / socialsciences.scielo.org/scielo.php?script=sci_arttext\&pid=S032777122006000100005, (15 Temmuz 2020)

Urhan, V. (2013). Michel Foucault ve Düşünce Sistemleri Tarihi Arkeoloji, Soykütüğü, Etik. İstanbul: Say Yayınları.

Whitebook, J. (2005). “Against Interiority: Foucault's Struggle with Psychoanalysis", Gary Gutting (Ed), The Cambridge Companion to Foucault, New York: Cambridge University Press, 312-347. 